\title{
Revoked License
}

National Cancer Institute

\section{Source}

National Cancer Institute. Revoked License. NCI Thesaurus. Code C118407.

The permanent cessation to permissions accorded to an active license. 